\title{
COVID-19 \& Obstructive Sleep Apnea: Association and Management
}

\author{
Mohit $^{1,2}$, Neeti Solanki ${ }^{1}$, Pranjali Dutt ${ }^{1}$, Pooran Dutt Chand ${ }^{1 \star}$ \\ ${ }^{1}$ Department of Prosthodontics, Faculty of Dental Sciences, King George’s Medical University, Lucknow, Uttar Pradesh, India \\ ${ }^{2}$ Center For Advance Research, King George’s Medical University, Lucknow, Uttar Pradesh, India
}

\begin{abstract}
Asian Journal of Complementary and Alternative Medicine. Volume 09 Issue 2
\end{abstract}
Published on: 20/05/2021

*Author for Correspondence: Dr. Pooran dutt Chand, Professor \& Head, Department of Prosthodontics, King George's Medical University, Lucknow-226003; E-mail: dr.pooran_chand@yahoo.com; Phone: 9415173419

Cite this article as: Mohit, Solanki N, Dutt P, Chand PD. COVID-19 \& Obstructive Sleep Apnea: Association and Management. Asian Journal of Complementary and Alternative Medicine, Vol 9(2), 42-43:2021.

Kyewords: Obstructive sleep apnea, COVID-19 pandemic, CPAP managment.

The rate and severity of COVID-19 transmission has elevated the morbidity and mortality rate across the world with failure of respiratory system being the major cause. The corona virus approach the cells through ACE-2 receptorand induce cytopathic effect triggering the pro-infalmmatory marker against the lung damage [1]. Therefore, induction of cytokines like IL6, ferritin, IL-8, leptin amongst others may contribute to the most prevailing sleep-related respiratory disorder, Obstructive sleep apnea (OSA) [2]. OSA is characterized by intermittent hypoxia, which can further deteriorate the COVID-19 associated hypoxemia and prompt the pulmonary damage. Hence, OSA by itself puts at risk of COVID-19 complications and increase the mortality rate. Moreover, literature suggests the association of OSA with various comorbidities such as diabetes mellitus, chronic respiratory issues, cardiovascular disease, hypertension, cerebrovascular disease etc., which might be more likely to develop complications of COVID-19 than other individuals considering the present statistics. Thus, OSA requires special assistance and, the management of OSA should be stressed upon for prevention and control [3].

The OSA patient with intermittent hypercarpnia and COVID-9 induced hypoxemia disturb the cardio metabolic pathway against the occluded airway and appear as cardiovascular disease [4].In addition, the binding of COVID-19 spike protein with ACE-2 receptor elucidate their entry and regulates the hypertension in mild to moderate with early diagnosed OSA patients. Furthermore,ACE-2 zinc motif peptidase dependently disgrace the bradykinin and impare the nitric oxide production which can influence the various pathological role of cardiovascular risk and hypertension with increase COVID-19 mortality rate [5].
Thus, to reduce the COVID-19 complications in OSA patients, utilization of continuous positive airway pressure (CPAP) has been suggested which is the gold standard of management of OSA. As COVID 19 spreads through droplet transmission, certain guidelines and recommendations needs to be followed while using CPAP. Accordingly,the aim and objective of this communication is to enhance the efforts for prevention, treatment, management, and better patient care, with improved quality of life. This should be very helpful to patients who routinely use positive airway pressure therapy (CPAP).

\begin{tabular}{|c|l|}
\hline S.No & \multicolumn{1}{|c|}{ Guidelines } \\
\hline 01 & $\begin{array}{l}\text { OSA patients should use the CPAP machine in } \\
\text { continuation at home as normal. [6] }\end{array}$ \\
\hline 02 & $\begin{array}{l}\text { The control of infection followed by routine } \\
\text { respiratory hygiene to be followed such as surface } \\
\text { and cleaning of equipment with hot soapy water and } \\
\text { continous change of machine filters. [7] }\end{array}$ \\
\hline 03 & $\begin{array}{l}\text { The quality and quantity of mask and tubing to be } \\
\text { maintained without over storing keeping in mind a } \\
\text { probable temporary shortage in future.[8] }\end{array}$ \\
\hline 04 & $\begin{array}{l}\text { CPAP machines and mask not to be co-shared with } \\
\text { anyone to prevent transmission of infection [9] }\end{array}$ \\
\hline 05 & $\begin{array}{l}\text { Only emergency patients encouraged to visit hospitals, } \\
\text { routine out-patient visits should be avoided unless } \\
\text { urgent. [10] }\end{array}$ \\
\hline 06 & $\begin{array}{l}\text { CPAP not to be used by the patients until instructed by } \\
\text { clinicians. [11] }\end{array}$ \\
\hline 07 & $\begin{array}{l}\text { Use of a humidifier with CPAP machine can be } \\
\text { avoided to reduce the droplet spread decreasing the } \\
\text { risk of COVID-19 infection. }\end{array}$ \\
\hline
\end{tabular}




\section{REFERENCES}

1. Mirzaei R, Karampoor S, Sholeh M, Moradi P, Ranjbar $R$, et al (2020) A contemporary review on pathogenesis and immunity of COVID-19 infection. Molecular biology reports; 47(7):5365-5376.

2. Tay MZ, Poh CM, Renia L, MacAry PA, Ng LFP (2020) The trinity of COVID-19: immunity, inflammation and intervention. Nature reviews Immunology; 20(6):363-374.

3. Bonsignore MR, Baiamonte P, Mazzuca E, Castrogiovanni A, Marrone O (2019) Obstructive sleep apnea and comorbidities: a dangerous liaison. Multidisciplinary respiratory medicine; 14:8.

4. Yacoub M, Youssef I, Salifu MO, McFarlane SI (2017) Cardiovascular Disease Risk in Obstructive Sleep apnea: An Update. Journal of sleep disorders \& therapy; 7(1).

5. Gheblawi M, Wang K, Viveiros A, Nguyen Q, Zhong JC, et al. (2020) Angiotensin-Converting Enzyme 2: SARSCoV-2 Receptor and Regulator of the Renin-Angiotensin System: Celebrating the 20th Anniversary of the Discovery of ACE2. Circulation research; 126(10):1456-1474.

6. Miech EJ, Bravata DM, Yaggi HK, Austin C, Tobias LA, et al. (2019) Adapting Continuous Positive Airway Pressure Therapy to Where Patients Live: A Comparative Case Study. Cureus; 11(2):e4078.
7. Weisel KC, Morgner-Miehlke A, Petersen C, Fiedler W, Block A, et al. (2020) Implications of SARS-CoV-2 Infection and COVID-19 Crisis on Clinical Cancer Care: Report of the University Cancer Center Hamburg. Oncology research and treatment; 43(6):307-313.

8. Bauchner H, Fontanarosa PB, Livingston EH (2020) Conserving Supply of Personal Protective Equipment-A Call for Ideas. Jama; 323(19):1911.

9. Mercieca L, Pullicino R, Camilleri K, Abela R, Mangion SA, et al. (2017) Continuous Positive Airway Pressure: Is it a route for infection in those with Obstructive Sleep Apnoea? Sleep science; 10(1):28-34.

10. Uscher-Pines L, Pines J, Kellermann A, Gillen E, Mehrotra A (2013) Emergency department visits for nonurgent conditions: systematic literature review. The American journal of managed care; 19(1):47-59.

11. Kushida CA, Chediak A, Berry RB, Brown LK, Gozal D, et al. (2008) Clinical guidelines for the manual titration of positive airway pressure in patients with obstructive sleep apnea. Journal of clinical sleep medicine : JCSM : official publication of the American Academy of Sleep Medicine; 4(2):157-171. 